\title{
3201 未固結軟弱な砂れき層に対する固化試錐法
}

\begin{tabular}{|c|c|c|c|}
\hline 資源技術試験所採釷保安部第 1 課長 & 栗 & 原 & - \\
\hline 資源技術試験所採捈保安部 & ○伊 & 藤 & 福 \\
\hline
\end{tabular}

近時，たとえば海底地下資源の開発の一環として，砂 鉄などの沖積散床の精査のために, 未固結軟弱な砂れき 層から完全なコアを採取する方法および技術が注目さ れ，これについての各種の研究や現場試験が試みられて いる。元来, 未固結軟弱な地層からコアを擾乱すること なく, 完全に採取することは, 試錐機の機構, 試錐技術 などの人為的条件および地層の状態, 環境などの自然的 条件により困難とされ, 現在においては未だ満足すべき 試錐法は見当らない。

この問題に対して, 当所では固化試錐法について, 研 究を進めて扣り，その一部に関してはすでに発表した。

すなわち，岕らがめ被コア採取带をアクリル・アミ

ドなどの固化剤により固化した後, クラウンビットによ り追い切りし，ドーナッッ状のコアを採取する方法につ いて述べたが，今回はこの方法の欠点を補つた新しい試 錐法, はすなわち, 未固結軟弱なコアを地層中で形成さ せた後ユニット・カプセル中に収容し，ここで固化させ て回収する方法について研究したので報告する。

今回試作した固化試錐機は第 1 図にその主要部を略図 として示したように，ダブル・コア・チューブ, ビット 回転駆動装置, ニニット・カプセル拈よびスラスターと から構成されている。ダブル・コア・チューブの中には 翼型油圧モータおよび給水管が蔵され，さらにコア・チ ニーブの最先端にはビットが取り付けられている。油圧

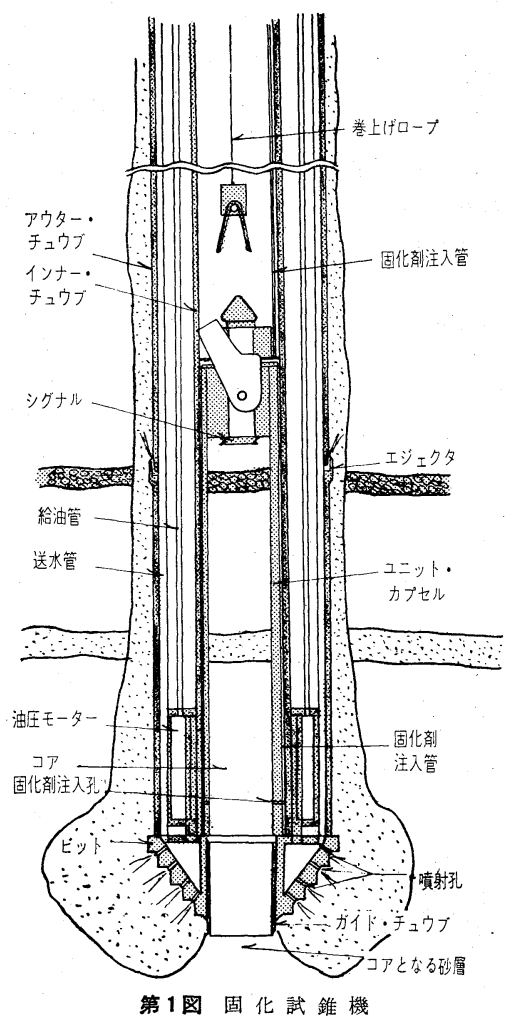

Vol. 82 No. $935(' 66-3)$
モータはビットと直結され，ビットにクランプ回転を与 え，給水管もまたビットに直結され，ビットの外側に開 けれた噴射孔より圧力水を噴射するようになつている。

このような試錐機を未固結軟弱な砂れき層に挿入し， コアとなる部分が残るように，その周囲の砂れき層を圧 力水により崩壊するとともに, 残されたコアを直ちに二 ニット・カプセル中に収容する。収容したコアはユニッ ト・カプセル中で固化し, ワイヤー・ラインにより巻き 上げ回収する。以下同様な操作を繰り返えしながら掘進 していく。

このような試錐法においては，コアを擾乱することな く, その周囲の砂れき曜を崩壊させることはこの方法の 成否を決定する重要な問題である。この問題に関する諸 因子（i）ビットの回転速度，(ii) 送り速度，(iii）ビ ットの形状，(iv) 噴射孔の直径，(v) 圧力水の圧力な どとコアの回収状態との関係について検討し, 次のよう な結果を得た。

実験装置は総油圧駆動式の試錐試験装置を用いた。主 な仕様は次のと打りである。

$$
\begin{array}{ll}
\text { スピンドル内径: } & : 165 \mathrm{~mm} \\
\text { 回転数 } & : 0 \sim 450 \mathrm{rpm} \text { 無段切換え } \\
\text { ストローク } & : 1,500 \mathrm{~mm}
\end{array}
$$

ダブル・コア・チューブの中に長さ $1 \mathrm{~m}$ のアクリル管 を蔵した長さ $2.5 \mathrm{~mm}$ の掘り管をスピンドルにセットし， 回転数技よび送り速度を変化させながら砂層からコアを 採取した。実験に供した砂層は $10 \mathrm{~cm}$ ずつ色分けして突 き固めた互層である。

ビットの回転数とコア採取率々の関係について検討し た結果, 良好なコアを採取し得るビットの回転数はビッ ト内径によつてやや異なるが，一般的に $10 \mathrm{rpm}$ 以下の 極低速回転であり，回転方向は一方向よりも往復回転の 方が好ましいことがわかつた。

なた, 送り速度は $15 \mathrm{~cm} / \mathrm{min}$ 前後が適当であつた。

一方，アクリル樹脂管に侵入したコアを検討した結果 第 2 図に示したように，掘り管の挿入長（掘進長さ）々 コアの収容長さとの関係は指数函数で表わされた。この ことから，良好なコアを採取することができる長さ（一 度の掘進長さ）に限度があることが推測される。

ビットの形状, 噴射孔の直径, 圧力水の圧力は, ジェ
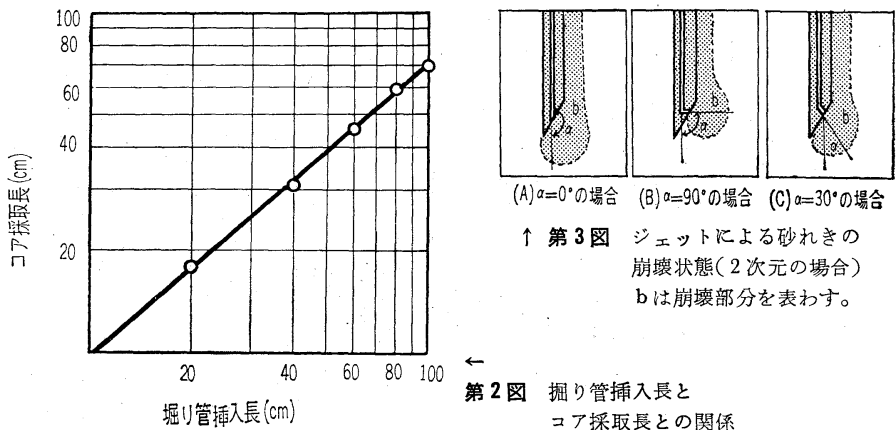

(A) $\alpha=0^{\circ}$ の場合 (B) $\alpha=90^{\circ}$ の場合 (C) $a=30^{\circ}$ の場合

$\uparrow$ 第3図ジェットルよる砂れきの 崩壊状態 ( 2 次元の場合) b は崩壊部分を表わす。

\section{$\leftarrow$}

堀り管軲入長 $(\mathrm{cm})$ 
ットによる砂れきの崩壊状態を究明することによつて決 定される。理想噴流についてはなく数多くの研究が行な われており，2次元噴流，3次元梖流の場合についての 速度分布が定量的に明らかにされている。しかし，ジェ ットによる砂れきの崩壊に対して，これを直ちに適用す ることはできない。そこでビットの模型を作り，2 次元
および 3 次元の場合のジェットによる砂れきの崩壊状態 を観察した。第 3 図は 2 次元の場合におけるジニットに よる砂れきの崩㙥状態を示す一例を示したものである。

これらの実験を通して直径 $80 \mathrm{~mm}$ のコアを採取し得る 固化試錐機を試作した。

\section{2 ボーリングに関する基礎的研究}

\author{
東北大学工学部教授・工博 堀部 \\ 東北大学工学部助教嗳・工博 小林 \\ 富男(正会員) \\ 良二(正会員)
}

ボーリングに関する研究は従来より数多く報告1)22さ れているが，穿孔性能の低下に最主重要な影響を与学る と考兄られるビットの摩耗の研究は少ないようである。 とくに摩耗量の測定はもつぱら摩耗幅に対して行なわ れ，摩耗高さ関しては測定困難のためかその例が漂と えど見岕たらない。

そこで筆者らは鉣研式 OP-1 型試錐機によるボーリン グ試験を行ない，ビットの刃先の摩耗を工場顕微鏡に上 り測定し穿孔長との関連に扣いて摩耗の進行状況を観察 した。さらに穿孔時に排出される繰粉の粒度分布々穿孔 特性との関係などについてり考察を試みたのでその結果 について報告する。

本研究に用いた試錐機第 1 図のよ5に推力，押上力 は新钿通信製の庄カヘッドを使用し，またトルクはク口 スストレンゲージをロッドに張り付けてスリップリング を通して取り出し，いずれもダイナミックストレンメー タ学通して電磁オッシロへ接続した。杂た穿孔速度の測 定は差動トランスを用い変位測定器を通して電磁オッシ ロへ，回転数は電磁型のヘッドを用いて同じく電磁オッ
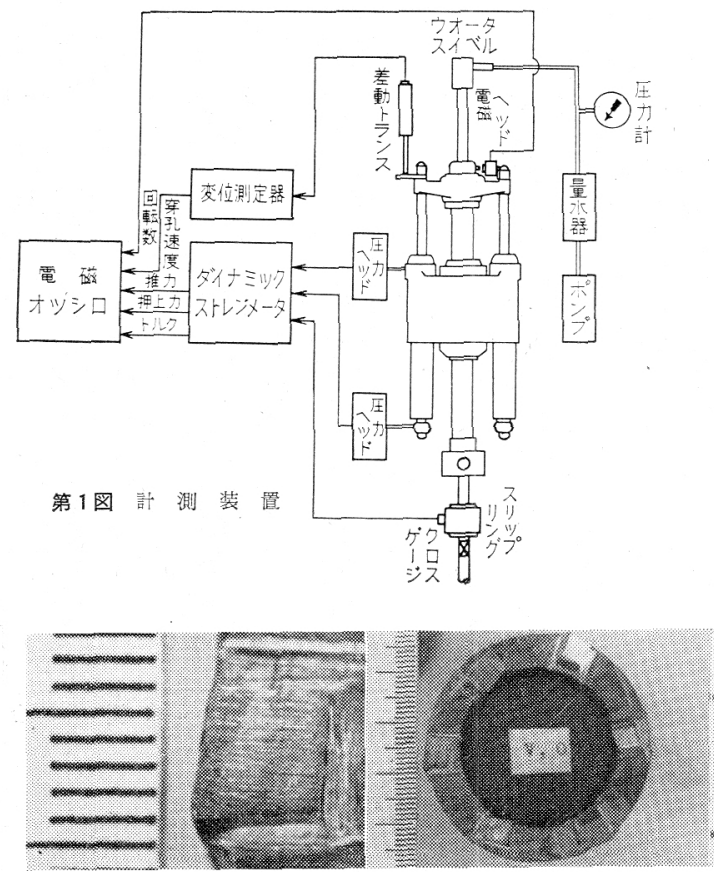

使用前の刃の状態 つた。
東北大学工学部助手 $\bigcirc$ 牛田

稔(正会員) 東北大学工学部大学院学生 伊藤

シロへ接続した。な拈給水量は量水器により別汇読み取

本研究で対象にしたメタルビットは同じく鈗研製の呼 び径 $46 \mathrm{~mm} 6$ 枚疒のコアビットで, 市販品を加工せずに 使用した。このビットは为先角約 $90^{\circ}$, 逃げ角約 $20^{\circ}$ でめ る。また穿孔に用いた岩石試料は宮城県登米郡石越町产 安山岩(石越石), 茨城県笠間市産花崗岩 (稻田久かげ) などである。実験に心たつては推力 $500 \mathrm{~kg}$, 回転数 125 $\mathrm{rpm}$, 給水量 $30.6 \mathrm{l} / \mathrm{min}$ の一定条件で穿孔を行ない，ビ ットの使用限界は一応穿孔速度が $1 \mathrm{~cm} / \mathrm{min}$ に低下与る までと考えて実験を行なつた。

摩耗の測定はニコン A II 型工場顕微鏡を使用して第 2 図のような要領で行なつた。すなわら本研究における穿 孔は回転切削でめるから, 刃先の摩耗条件はビットの中 心からの距離によつて異なるはずである。それゆえビッ トの摩耗を個々の刃先について計測するよりも，ビット の中心より等距離にある刃先上の点を統計的に計測する 方がより合理的であると思われるので，ビットの中心か ら $1 \mathrm{~mm}$ 毎の同心円を考光，摩耗幅は中心からの距離と その角度から算出して同一半径の同心印上の 3 枚または 6 枚の刃の值の平均值を求めることとした。また同時に 刃の高さは同心円上の未使用時の稜線の位置々摩耗部の 前縁, 後縁の 3 篃所について読み取つたが，いずれも大 差がないので未使用時の稜線の位置についての高さを用 いることとし，摩耗幅の場合と同様に同一半径の同心円 上の 3 枚または 6 校の刃の平均值を求好。なお刃先の 高さは台金を基準として表わすのが適当と思われるが， 穿孔時に台金が摩耗して測定值保差老生ずるおそれが 岁る。そのため台金にポンチを打つてポンチ孔底を基準 として刃先の高さを測定することとし，穿孔中はポンチ 孔をパラフインで保護した。

次に実験結果の一例として安山岩に対し穿孔した場合 のビットの摩耗の様子を示せば例壳ば第 3 図のと括りで 岁る。すなわち䋡軸は刃の平均高さ, 横軸はビットの中 心からの距離をとつたものである。この図より窒孔長の 增加炕したがつて刃は打扣よそ比例して摩耗し, 最外

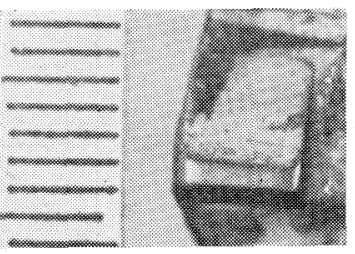

$450 \mathrm{~cm}$ 穿孔後の刃の状態 第 2 図 刃先の摩耗の状態ならびに摩耗測定法

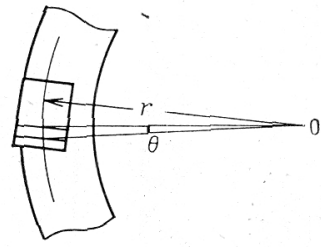

$r:$ ビットの中心からの距雔 $\theta$ : 摩耗幅偣詨する角度 